\title{
Incorporation of particles into the bulk of expanded polystyrene foam using physical vapour deposition technologies
}

\author{
Šarūnas Varnagiris ${ }^{1^{*}}$, \\ Jolanta Donèliené \\ Simona Tučkutè \\ Tomas Vonžodas ${ }^{1}$, \\ Martynas Lelis ${ }^{1}$, \\ Darius Milčius $^{1}$ \\ ${ }^{1}$ Lithuanian Energy Institute, \\ Breslaujos str. 3, \\ LT-44403 Kaunas, Lithuania \\ ${ }^{2}$ UAB Modernios E-Technologijos, \\ Vismaliuku str. 34, \\ LT-10243 Vilnius, Lithuania \\ E-mailsarunas.varnagiris@lei.lt
}

\begin{abstract}
Expanded polystyrene foam (EPS) is used for various applications because of its significant properties (low weight, low cost, good thermal insulation, etc.). However, some of EPS characteristics should be improved. Because of this, additional materials are incorporated into polystyrene. This article presents the results of particles incorporation into EPS bulk using physical vapour deposition (PVD). $\mathrm{TiO}_{2}$ was used as an additional material, which was incorporated into EPS foam. Non-expanded polystyrene beads were used as a substrate. These beads were treated with argon plasma in order to achieve better surface adhesion. Plasma was generated at $1 \times 10^{-1} \mathrm{mbar}$ pressure using a pulsed DC power source (frequency $20 \mathrm{kHz}$, voltage $400 \mathrm{~V}$ ). Particles were deposited on the surface of non-expanded polystyrene beads. Titanium cathode was used as a primary material. The formation of particles was done using magnetron sputtering in reactive atmosphere. The mixture of argon and oxygen gas was used in order to form $\mathrm{TiO}_{2}$ particles (argon $82 \%$, oxygen $18 \%$ ). Vacuum pressure was $6 \times 10^{-3} \mathrm{mbar}$ during the particles formation process (power during deposition $240 \mathrm{~W}$ ). Results showed that $\mathrm{TiO}_{2}$ particles were formed on the surface of non-expanded polystyrene beads. These particles remained stable after expansion of beads and compounded in onepiece foam of EPS. Particles were distributed uniformly in all bulk of EPS and remained in place even after flame torch induced heat resistance experiments. The modified EPS also showed photocatalytic activity during the bleaching of methylene blue (MB) aqueous solution under UV-B irradiation.
\end{abstract}

Key words: expanded polystyrene foam, magnetron sputtering, torch induced heat resistance, photocatalytic activity

\section{INTRODUCTION}

Expanded polystyrene foam (EPS) is used for a wide variety of applications such as packing, safety materials, thermal insulation of buildings, other construction applications, etc. The use of expanded polystyrene foam is driven by a remarkable combination of properties (thermal insula- tion, low weight, low cost, etc.) [1-3]. The global predictable demand for polystyrene is supposed to reach 23.5 million tons by 2020 . A compound annual growth rate (CAGR) is $1.4 \%$ per decade since 2000. It reached 14.9 million tons per year in 2010. In the coming years, this market expects to have an even more impressive growth [4-5]. This growth and higher requirements promote 
manufacturers to find appropriate methods in order to produce even higher quality polystyrene foam. In particular, the biggest EPS manufacturers are trying to improve some of EPS characteristics such as resistance to fire, antibacterial characteristic, thermal insulation, etc. In order to improve these characteristics, additional materials should be incorporated into polystyrene foam.

Additive materials can significantly change the properties of the polymers into which they are incorporated. For example, they may change the viscosity, flexibility, density, tensile strength, and flexural strength. Normally, additives which are incorporated into polystyrene are used to increase fireproof and thermal insulation properties. These additives are phosphorous-based, silica-based materials, graphite oxides, etc. [6-8]. Furthermore, antibacterial characteristics of polystyrene should be improved. There are a lot of articles related to the mould formation in buildings and its influence on health and durability of buildings. In general, it is called the "sick building syndrome" [9-11]. Another problem is related with bacteria propagation in food when it is stored in industrial food containers. Consequently, materials or compounds which have antibacterial characteristics should be incorporated into polystyrene. One of these compounds is titanium dioxide. $\mathrm{TiO}_{2}$ is a widely used commercial material with a multitude of applications. Titanium dioxide is used for wastewater cleaning, antibacterial effect, super-hydrophilicity/self-cleaning and other applications [12].

The most common technique used to add materials in polymers is to physically mix all components to form polymer/additives blends [13-15]. During the first step of this technique, polystyrene foam has to be prepared forming expanded PS beads and only then the product is mixed with additional materials in mixing bowls. However, due to low adherence of particles to polymer materials when using such mixing method, particles can easily detach from polymers. In this case, polystyrene loses characteristics which should be improved [16-17]. In order to avoid this, alternative deposition methods, which could lead to a better polymer substrate-particle adherence, should be used. Yu et al. in their work [18] showed that PVD could be a suitable method to deposit particles on EPS. However, it is known that polymers are thermally sensitive materials. Because of this, it is hard to deposit particles on the surface of polystyrene without any prejudice of EPS. Economical and efficient particle and film formation onto thermally non-stable substrates still remains a challenge for scientists and industry.

This work presents the results of particles formation onto primary polystyrene beads before the expansion process. Coated polystyrene beads were expanded and moulded into the required form foam. Particles-polystyrene adherence and stability were tested using flame torch induced heat resistance experiments. Photocatalytic properties of $\mathrm{TiO}_{2}$ particles incorporated into EPS foam have been investigated by bleaching methylene blue aqueous solution under UV-B irradiation.

\section{METHODOLOGY}

\section{Formation of $\mathrm{TiO}_{2}$ clusters}

$\mathrm{TiO}_{2}$ formation was done using a modified physical vapour deposition (PVD 75) system manufactured by Kurt J. Lescer company (Fig. 1). The vacuum system consisted of a rotary pump and a Cryopump with the ultimate achievable pressure bellow $10^{-8}$ mbar. The ratio of the supplied argon and oxygen working gases (99.999\% purity; $A G A$ company, a member of The Linde Group) was monitored and controlled by the integrated computer system. Plasma pretreatment was done in order to remove organic contaminants from the surface and increase free-surface energy of the polymer beads and significantly improve clusters adhesion [19-21]. Argon gas plasma was used in the plasma pretreatment process. Gas pressure during plasma pretreatment was set to $1 \times 10^{-1}$ mbar. Plasma was generated using $97 \mathrm{~W}$ power supplied by a pulsed DC power source (combination of $\mathrm{AE}$ Pinnacle 3000 and AE Sparc-le). The distance between polystyrene beads and a high temperature stainless steel (made from Alloy 600) cathode was $40 \mathrm{~mm}$, activation time $40 \mathrm{~s}$. The described set of polystyrene beads activation parameters was preselected experimentaly finding optimal conditions. Polystyrene beads were rotated by 180 degree after plasma activation. Beads were placed directly under the magnetron. The Ti cathode was used as a source of titanium particles. A $76.2 \mathrm{~mm} \mathrm{Ti}$ cathode was used as a source of titanium particles. The distance between $\mathrm{Ti}$ magnetron and polystyrene beads was $70 \mathrm{~mm}$. Gas pressure was kept 


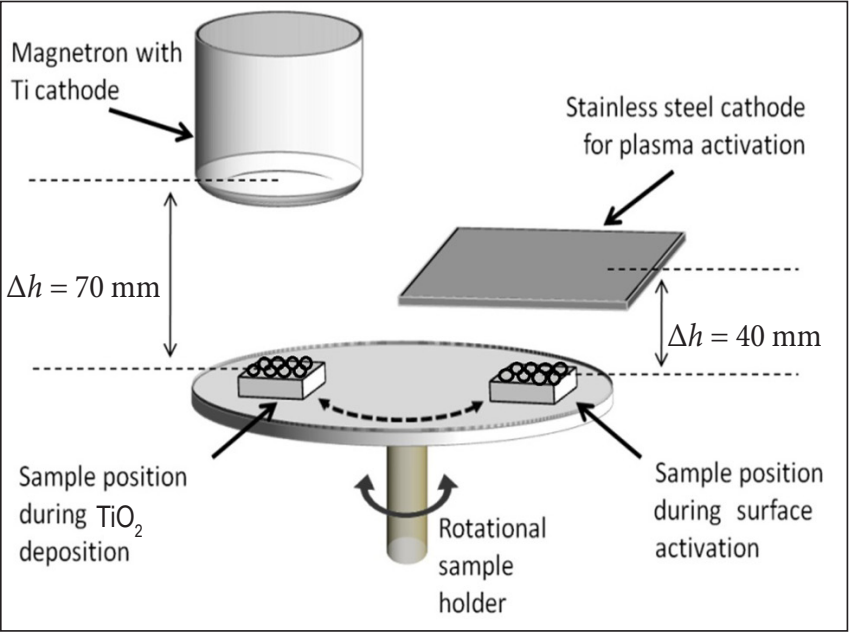

Fig. 1. Scheme of experimental set-up of the vacuum system and sample position during polystyrne beads activation (right) and $\mathrm{TiO}_{2}$ particles deposition (left)

constant at $6 \times 10^{-3}$ mbar during reactive deposition of titanium oxide clusters. The mixture of argon and oxygen gas was used in order to form $\mathrm{TiO}_{2}$ particles (argon 82\%, oxygen 18\%). Reactive sputtering was conducted with $0.7 \mathrm{~A}$ (power $240 \mathrm{~W}$ ). Magnetron current was maintained by a pulsedDC power source. Polystyrene beads were coated by three steps of 3 hours each ( 9 hours in total). Between second and third steps, polystyrene beads were taken out from the vacuum chamber and thoroughly mixed. Then polystyrene beads were put back and the deposition process was continued as soon as a proper vacuum level was obtained (roughly $30 \mathrm{~min}$ ). The mixing of beads is essential, because clusters could be deposited just on one side of beads. With mixing, beads are coated more uniformly. To avoid beads overlapping, the maximal amount of polystyrene beads was limited to $10 \mathrm{~g}$ per one deposition cycle.

\section{Expansion of polystyrene beads}

The expansion of polystyrene beads was done by colaboration with UAB Modernios E-Technologijos. This process was done using the laboratory-made polystyrene beads expansion equipment. After expansion and moulding processes, the dimen- sions of an expanded polystyrene foam block was $200 \times 200 \times 50 \mathrm{~mm}$. In order to obtain $20 \mathrm{~kg} / \mathrm{m}^{3}$ density of expanded polystyrene foam, $40 \mathrm{~g}$ of coated non-expanded polystyrene beads were used. The manufacturing of expanded polystyrene foam consists of several steps. The first step is pre-expansion of polystyrene beads. During this process, the flow of water steam (about $95^{\circ} \mathrm{C}$ ) is passed through the polystyrene beads. The boiling point of pentane, which is inside polystyrene beads is $35.9^{\circ} \mathrm{C}$. Because of this, pentane leads to expand beads. Polystyrene beads are expanded after several minutes during this process. the second step is the ageing of pre-expanded polystyrene beads for at least 24 hours. This allows air to diffuse into the beads, cooling them and making them harder. Then beads are transferred into a moulding vesel. There, the flow of water steam is passed through the pre-expanded polystyrene beads once again. However, pressure during this process is set to $6 \times 10^{2}$ mbar. The time of this process is about 1 minute. Low pressure and water steam leads to expand and mould them together into one piece.

Full steps of EPS foam manufacturing with particles inside are shown in Fig. 2. It could be seen that the full manufacturing process consists

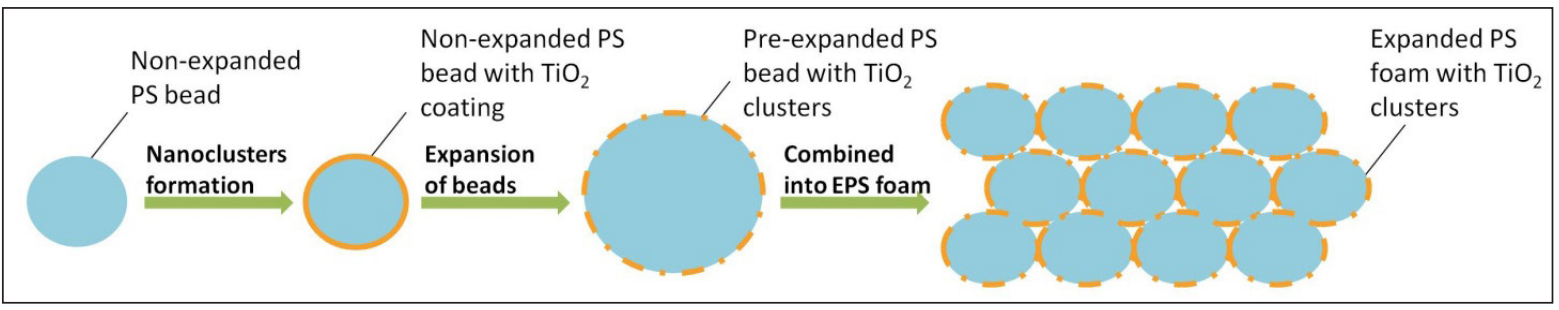

Fig. 2. Principle scheme of EPS foam formation with clusters (green arrows - manufacturing processes, blue - state of polsytyrene) 
of three main steps (green arrows). First, coating on PS beads should be deposited. Then these beads are expanded and $\mathrm{TiO}_{2}$ coating cracked into small clusters. Finally, beads are moulded into one foam. During this process, polystyrene beads go over three conditions: primary PS beads, pre-expanded beads, and beads moulded into foam (Fig. 3).

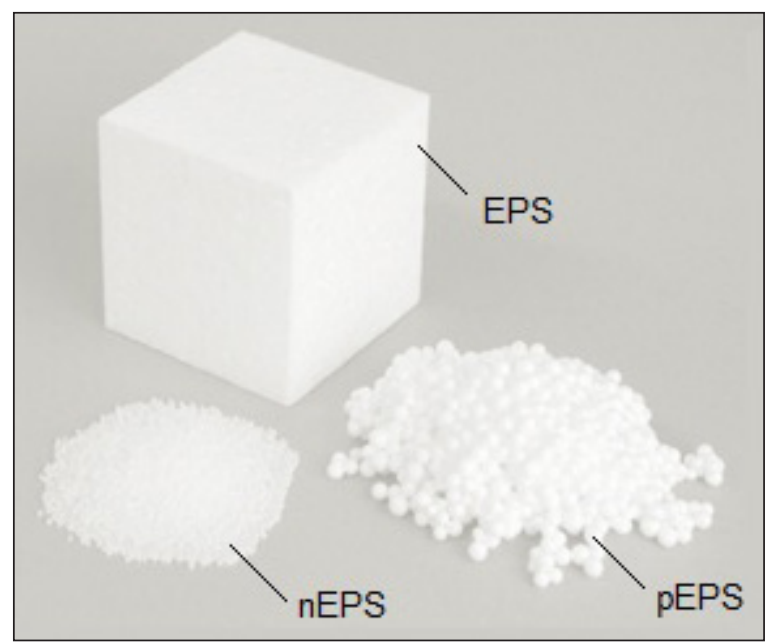

Fig. 3. Polystyrene: nEPS - non-expanded polystyrene beads, pEPS - pre-expanded polystyrene beads, EPS - expanded polystyrene foam

\section{Characterization of $\mathrm{TiO}_{2}$ clusters}

The measurements of surface morphology were performed with a scanning electron microscope (SEM, Hitachi S-3400N) using a backscattered electron detector. The measurement of elemental surface composition was done by using an X-ray energy dispersive spectroscope (EDS, Bruker Quad 5040).

Chemical analysis of $\mathrm{TiO}_{2}$ coated polystyrene was performed with an X-ray photoelectron spectrometer (PHI 5000 Versaprobe). The main XPS parameters were: monochromated $1486.6 \mathrm{eV} \mathrm{Al}$ radiation, $25 \mathrm{~W}$ beam power, $100 \mu \mathrm{m}$ beam size, and $45^{\circ}$ measurement angle. Survey scan was performed using $115 \mathrm{eV}$ energy throughput, $1 \mathrm{eV}$ step; spectra of individual elements were recorded with $23.5 \mathrm{eV}$ energy throughput, $0.1-0.2 \mathrm{eV}$ step for $20-35 \mathrm{eV}$ window (depending on element). Sample charging was compensated using a dual neutralization system consisting of a low energy electron beam and an ion beam. Energy calibration was done by measuring $\mathrm{C} 1 \mathrm{~s}$ peak of anthropogenic carbon and fixing it at $285.0 \mathrm{eV}$. XPS spectra processing and analysis was done using Multipak software and NIST Standard Reference Database.

In order to estimate particles adherence to the polystyrene substrate, flame torch induced heat impact tests were performed on the EPS samples with $\mathrm{TiO}_{2}$ particles using a custom build testing set-up presented in Fig. 4.

Photocatalytic properties of samples with $\mathrm{TiO}_{2}$ particles incorporated into EPS foam have been investigated by bleaching methylene blue (MB) aqueous solution under UV-B irradiation. For these tests, samples were cut into discs of $3 \mathrm{~mm}$ thickness and 41-42 $\mathrm{mm}$ diameter and inserted into extra-depth Petri dishes of $40 \mathrm{~mm}$ diameter. When pressing a sample into a Petri dish, the discs of slightly larger diameter served as natural sealants to prevent $\mathrm{MB}$ solution from leaking bellow the sample. Then $6 \mathrm{ml}$ of $15 \mathrm{mg} / \mathrm{L}$ concentration of aqueous $\mathrm{MB}$ solution were syringed above the sample and the top of the Petri dish was covered by a $500 \mu \mathrm{m}$ thick fused silica disc to minimize evaporation of MB solution. The used UV-B light source was a narrow waveband $(305-315 \mathrm{~nm}$ with a peak at $311 \mathrm{~nm}) 9 \mathrm{~W}$ power Philips UV-B medical lamp (PL-S 9W/01/2p 1CT). The UV-B lamp was placed $70 \mathrm{~mm}$ above the sample. Before UV exposure, EPS samples with incorporated $\mathrm{TiO}_{2}$ particles were kept in darkness for 24 hours.

$\mathrm{MB}$ concentration in aqueous solution was measured by a UV-VIS spectrophotometer (Jasco

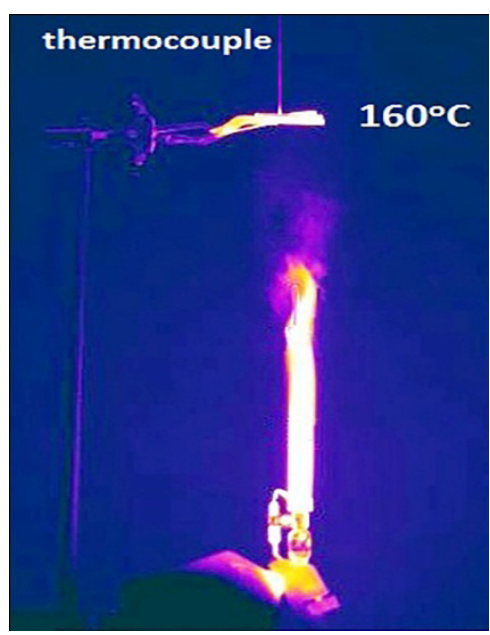

Fig. 4. Thermal image of experimental set-up during the heat impact test 
V-650) with the main parameters: full analysis wavelength range was $350-800 \mathrm{~nm}$, the strongest adsorption peak $(\approx 663 \mathrm{~nm})$ was used for MB concentration calibration curve and actual value measurements. Measurements were repeated regularly at 1 hour intervals with $1.5 \mathrm{ml}$ volume. Straight after the spectroscopic analysis (approximately 2 minutes), MB solution was syringed back to the Petri dish with the sample. All volumes of $\mathrm{MB}$ solution taken for the spectroscopic analysis and returned back to the irradiation as well as the initial and final total volume of the solution were carefully monitored and considered during data processing.

\section{RESULTS AND DISCUSSION}

The surface changes of polystyrene and results of $\mathrm{TiO}_{2}$ formation were observed using a scanning electron microscope (SEM). It could be seen that primary polystyrene beads have uneven surface (Fig. 5a). During reactive magnetron sputtering, the whole surface is covered by a thin $\mathrm{TiO}_{2}$ layer which fully repeats the curvature of the initial polystyrene bead surface (Fig. 5b). During the pre-expansion step, the surface area of polystyrene beads increases drastically. $\mathrm{TiO}_{2}$ is not as flexible as polystyrene; therefore, it cannot expand together with the beads (Fig. $5 \mathrm{c}$ ). Then pre-expanded polystyrene beads are moulded into a foam block. $\mathrm{TiO}_{2}$ clusters remain visible all over the surface (Fig. 5d). This means that $\mathrm{TiO}_{2}$ remains stable and not separated from the surface of polystyrene.

XPS analysis was done in order to understand chemical states of titanium and oxygen elements on the surface of polystyrene. Figure 6 shows the fitting results of O1s and Ti2p peaks after deposition on primary beads (Fig. 6a-b) and after pre-expansion of these beads (Fig. $6 c-d$ ). Results showed that Ti2p 3/2 peak was observed on $458.5 \mathrm{eV}$ binding energy. The difference between Ti2p $3 / 2$ and Ti2p $1 / 2$ is $5.70 \mathrm{eV}$. Ti2p possition $(458.5 \mathrm{eV})$ and the difference between these two Ti peaks showed that titanium dioxide was formed during the deposition process. The same result was observed after pre-expansion of polystyrene beads. This means that deposited $\mathrm{TiO}_{2}$ particles are not reacting with the water steam and remain stable during the expansion process. The results of O1s fitting showed that it consists of two components. A more intense component at roughly $530 \mathrm{eV}$ (Fig. 6a, c) can be attributed to $\mathrm{TiO}_{2}$, whereas the other component of O1s peak can be attributed to oxygen-carbon $(\mathrm{O}=\mathrm{C}, \mathrm{O}-\mathrm{C})$ compounds which might be coming from polystyrene beads themselves or it could be from interaction with atmosphere. Because of very similar binding energy of these compounds, it is hard to estimate precise areas of each compound [23].

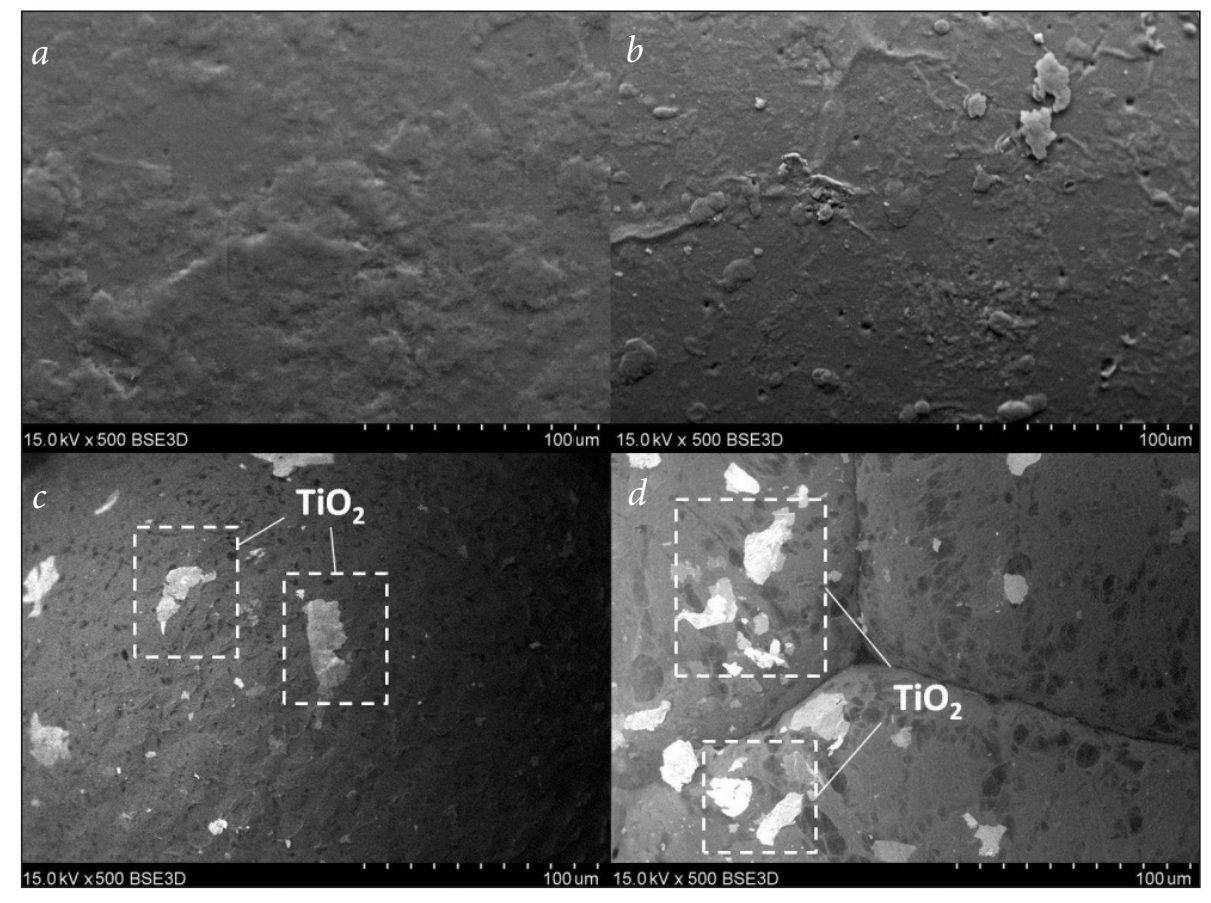

Fig. 5. SEM views of polystyrene: (a) primary polystyrene bead, $(b)$ bead after $\mathrm{TiO}_{2}$ formation, (c) bead after pre-expansion with $\mathrm{TiO}_{2}$ particles, (d) expanded polystyrene foam with $\mathrm{TiO}_{2}$ particles. Red dashed rectangles - some of $\mathrm{TiO}_{2}$ particles 


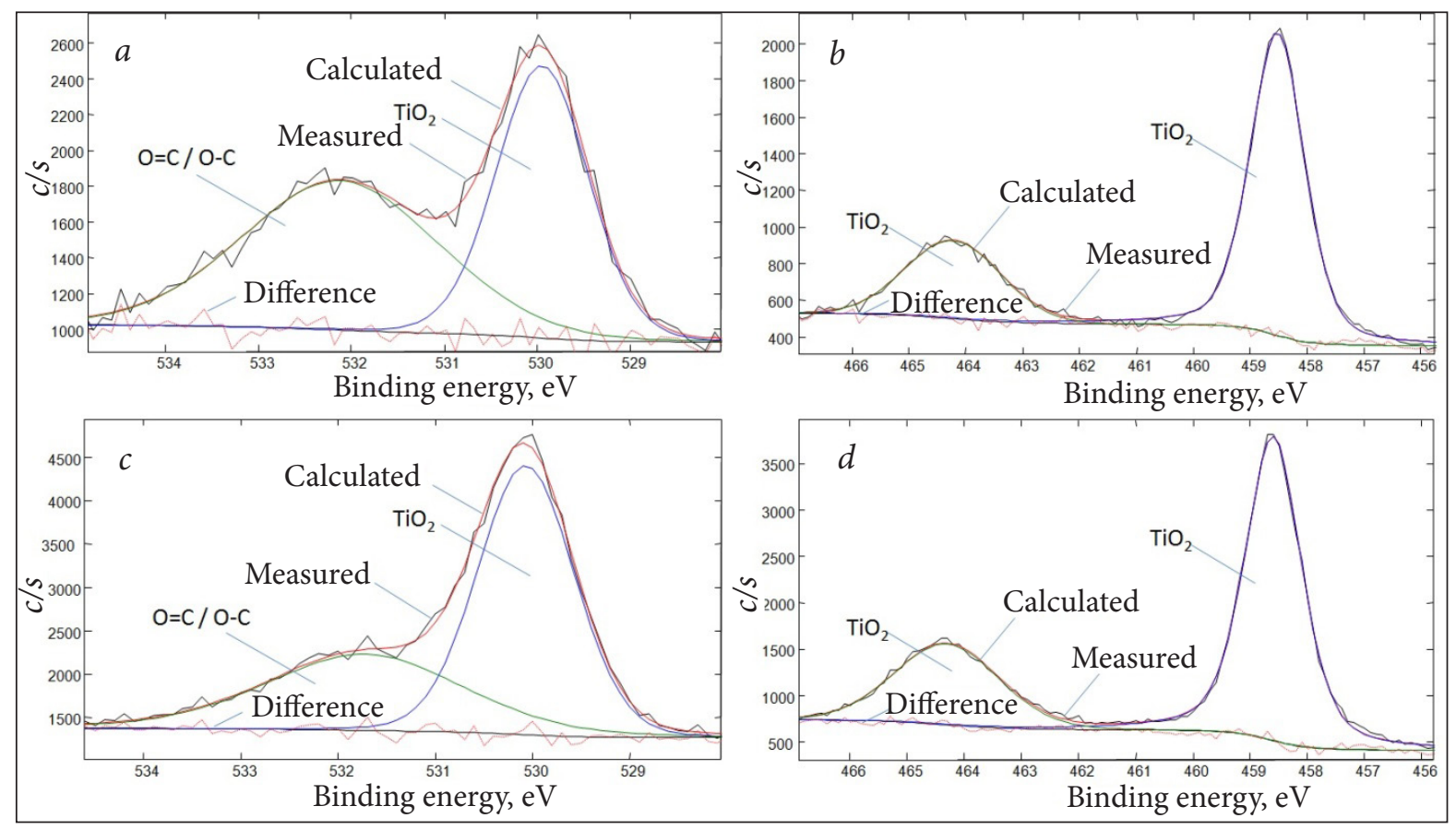

Fig. 6. XPS fitting of Ti2p and 01s peaks: (a) 01s peak after $\mathrm{TiO}_{2}$ formation on primary polystyrene beads, (b) Ti2p 3/2 and 1/2 peaks after $\mathrm{TiO}_{2}$ formation on primary polystyrene beads, (c) 01s peak after pre-expansion, (d) Ti2p 3/2 and 1/2 peaks after pre-expansion. "Difference" shows difference between measured and calculated lines
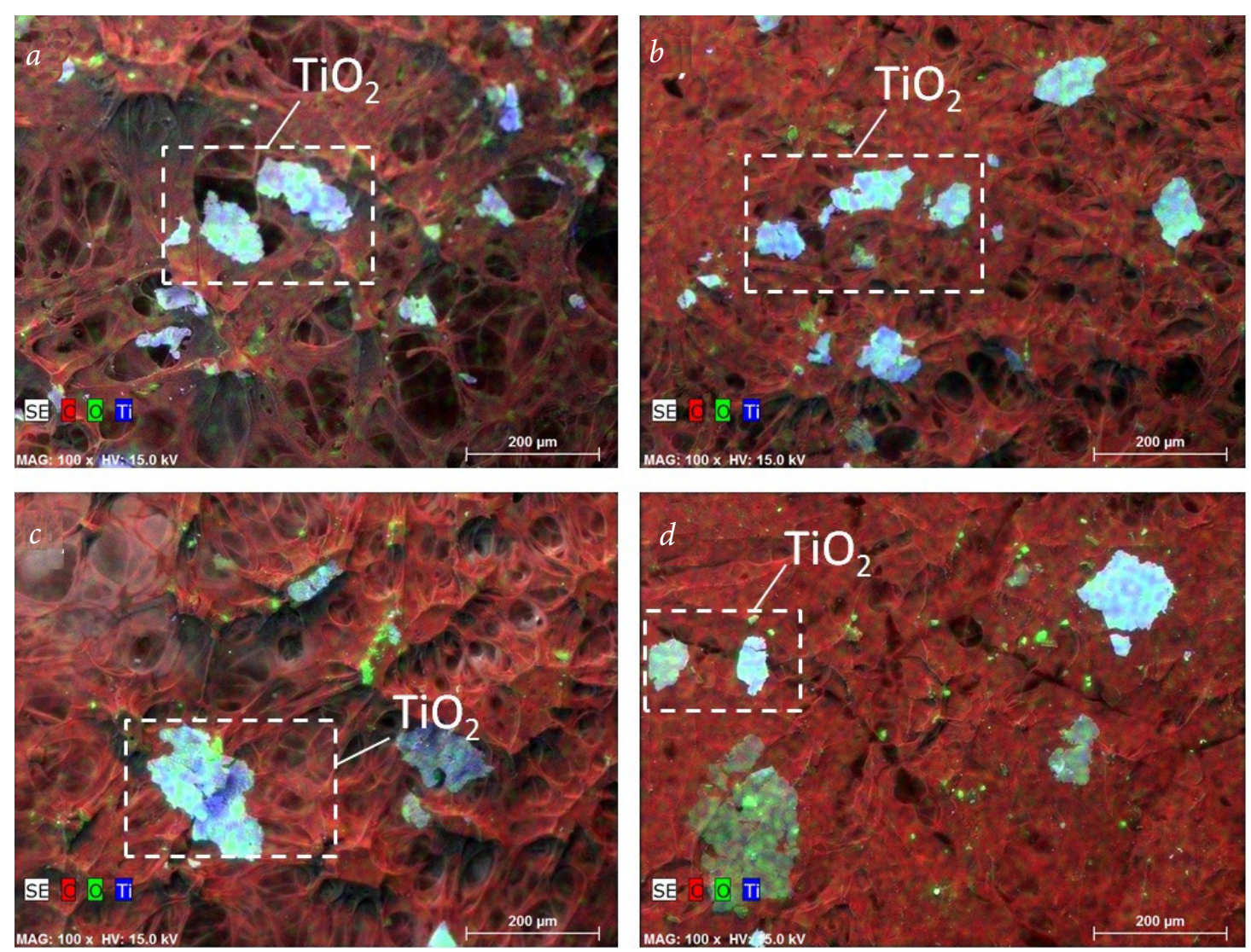

Fig. 7. Expanded polystyrene with $\mathrm{TiO}_{2}$ particles on the surface: ( $a$ ) after 5 seconds, $(b)$ after 30 seconds, $(c)$ after 50 seconds, (d) after 60 seconds of flame torch induced heat 
In recent years, lots of incidents related to ignition of polymer-based insulation materials were occurred. It was shown that during the contact with a heat source EPS could soften, melt, decompose, release flammable gases and burn [28, 29]. In order to understand EPS stability and $\mathrm{TiO}_{2}$ particles adherence to EPS foam in the present work, flame torch induced heat impact tests were performed on EPS with $\mathrm{TiO}_{2}$ particles samples.

Figure 7 confirms that EPS with $\mathrm{TiO}_{2}$ particles remains relatively stable during the flame torch induced heat impact test. EPS material surface melted and cellular structure changed to a more uniform partially melted one with increase of heat impact time from 5 to 60 seconds. $\mathrm{TiO}_{2}$ particles remained in the EPS structure, and it confirms an excellent adherence of additives to EPS. The photocatalytic activity of $\mathrm{TiO}_{2}$ incorporated into EPS foam was tested by studying the alteration of absorption of $\mathrm{MB}$ aqueous solution as a function of time (Fig. 8).

By measuring the peak intensity of the optical absorption spectrum, the decrease of $\mathrm{MB}$ concentration was estimated. It was observed that EPS with $\mathrm{TiO}_{2}$ particles incorporated into the EPS foam showed a better photocatalytic effect than EPS without any additives. It was demonstrated that MB concentration decreases with every hour of UV-B irradiation and the rate of concentration decreases with $\mathrm{TiO}_{2}$ additives remaining higher throughout the experiment. Of course, in absolute numbers the MB concentration difference after 8 hours is several percent which is not much; however, this result is obtained with $\mathrm{TiO}_{2}$ clusters covering only several percent of the total moulded EPS foam surface area. If higher density EPS foam (less expanded polystyrene beads) were used, the fractional surface area covered by $\mathrm{TiO}_{2}$ would be higher and this could increase the antibacterial effect significantly.

\section{CONCLUSIONS}

This paper presents the first systematic study of a new developed method of $\mathrm{TiO}_{2}$ particles incorporation into the bulk of EPS foam. $\mathrm{TiO}_{2}$ clusters were formed on the surface of primary polystyrene beads using the physical vapour deposition system. These beads were expanded and moulded into foam. XPS results showed that the $\mathrm{TiO}_{2}$ compound was formed on the surface of primary polystyrene beads. $\mathrm{TiO}_{2}$ was distributed relatively uniformly on the surfaces of polystyrene beads. $\mathrm{TiO}_{2}$ did not form any other compound nor did it separate from polystyrene beads surfaces during expansion and/or moulding processes. $\mathrm{TiO}_{2}$ particles also had almost excellent adherence to EPS, which was confirmed after flame torch induced heat impact tests. Photocatalytic properties of samples with $\mathrm{TiO}_{2}$ particles incorporated into EPS foam were investigated in methylene blue (MB) aqueous solution under UV-B irradiation, and results confirmed that these samples were more efficient in comparison to EPS without $\mathrm{TiO}_{2}$ additives.

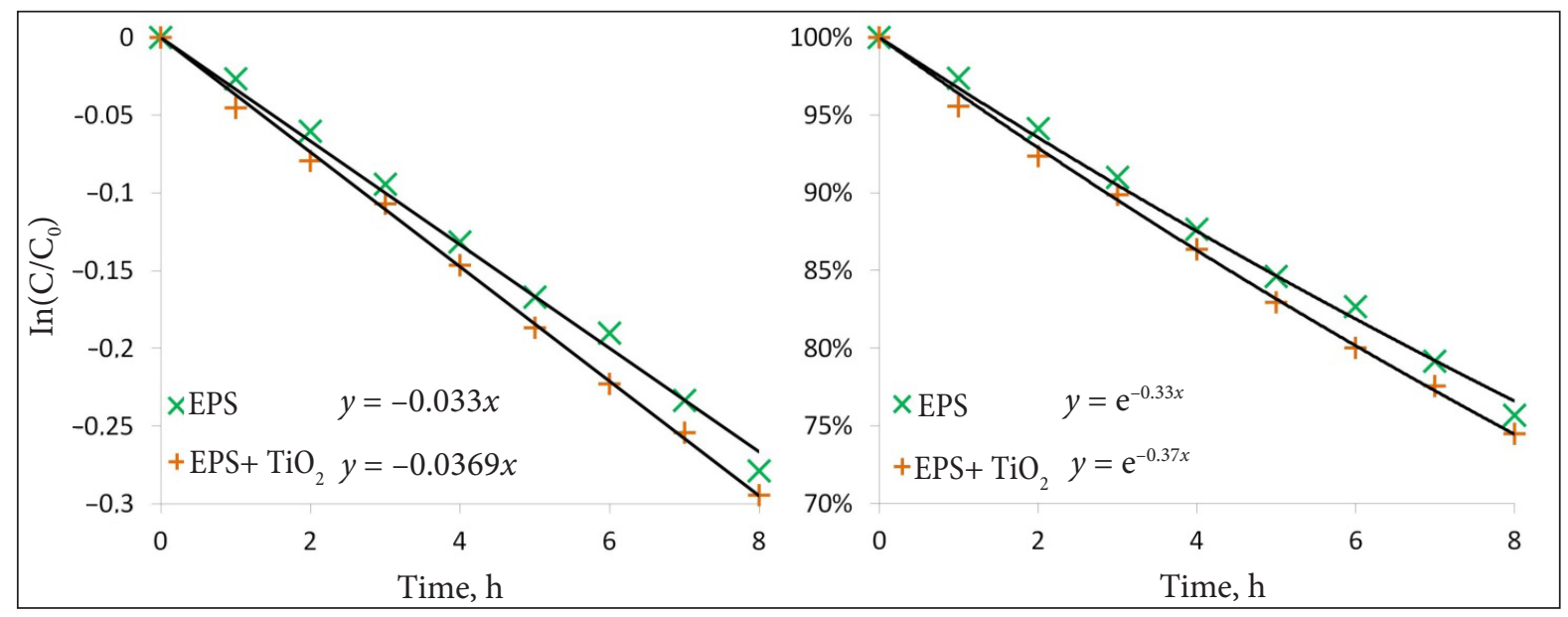

Fig. 8. Averaged concentration alteration of MB solution using UV-B irradiation when decomposition of MB solution is catalysed with $\mathrm{TiO}_{2}$ incorporated in EPS 


\section{ACKNOWLEDGEMENTS}

The work was financially supported by The European Social Fund under the project with SFMIS code: VP1-3.1-SMM-10-V-02-019.

Received 25 April 2016

Accepted 15 May 2016

\section{References}

1. Katan Z., Travas-Sejdic J., Hrnjak-Murgic Z. Study of flammability and thermal properties of high-impact polystyrene nanocomposites. Polymer Degradation and Stability. 2011. Vol. 96. No. 12. P. 2104-2111.

2. Deveci H., Ahmetli G., Ersoz M., Kurbanli R. Modified polystyrenes: Corrosion, physicomechanical and thermal properties evaluation. Progress in Organic Coatings. 2012. Vol. 76. No. 1. P. 1-7.

3. Kuo Y., Chang K., Hung T., Chen K., Inagaki N. Atmospheric-pressure plasma treatment on polystyrene for the photo-induced grafting polymerization of $\mathrm{N}$-isopropylacrylamide. Thin Solid Films. 2010. Vol. 518. No. 24. P. 7568-7573.

4. Polystyrene (PS) and Expandable Polystyrene (EPS) Global Market to 2020 - Continued Development in the Construction (EPS) and Packaging (PS) End-use Segments to Accelerate Future Demand. GBI. Chesham, 2012.

5. Hansen A. P., Silva G. A., Kulay L. Evaluation of the environmental performance of alternatives for polystyrene production in Brazil. Science of the Total Environment. 2015. Vol. 532. No. 1. P. 655-668.

6. Xia Y., Mao Z., Jin F., Guan Y., Zheng A. Synthesis of 1-hydroxy ethylidene-1,1-diphosphonic ammonium and the promise of this ammonium salt as an intumescent flame retardant in polystyrene. Polymer Degradation and Stability. 2014. Vol. 102. P. 186-194.

7. Hu W., Yu B., Jiang Sh., Song L., Hu Y., Wang B. Hyper-branched polymer grafting graphene oxide as an effective flame retardant and smoke suppressant for polystyrene. Journal of Hazardous Materials. 2015. Vol. 300. P. 58-66.

8. Liang Sh., Neisius N. M., Gaan S. Recent developments in flame retardant polymeric coat- ings. Progress in Organic Coatings. 2013. Vol. 76. P. 1642-1665.

9. Pietrzyk K. A systemic approach to moisture problems in buildings for mould safety modelling. Building and Environment. 2015. Vol. 86. P. 50-60.

10. Mendes A., Teixeira J. P. Sick building syndrome. Reference Module in Biomedical Sciences. 2014. Vol. 3. P. $256-260$.

11. Noma E., Berglung B., Berlung U., Johansson I., Baird J. C. Joint representation of physical locations and volatile organic compounds in indoor air from a healthy and a sick building. Atmospheric Environment. 1988. Vol. 22. No. 3. P. 451460.

12. Ola O., Maroto-Valer M. M. Review of material design and reactor engineering on $\mathrm{TiO}_{2}$ photocatalysis for $\mathrm{CO}_{2}$ reduction, Journal of Photochemistry and Photobiology C: Photochemistry Reviews. 2015. Vol. 24. P. 16-42.

13. Kim H.-K., Kwon T.-Y., Yun I.-K. Flame-retardant bead composition for producing flame-retardant expanded polystyrene foam and method of producing flame-retardant beads using the same. Patent WO 2009133975 A1, 2009.

14. Mosier B. Method of manufacturing fire retardant polystyrene insulating board. Patent US 4596682 A, 1986.

15. Mcketta J. J. Unit Operations Handbook. Volume 2: Mechanical Separations and Materials Handling. New York, 1993. P. 521-526.

16. United States Environmental Protection Agency. Flame Retardant Alternatives for HEXABROMOCYCLODODECANE (HBCD). Final Report, 2014. EPA Publication 740R14001.

17. Laotid F., Bonnaud L., Alexandre M., Lopez-Cuesta J.-M., Dubois P. H. New prospects in flame retardant polymer materials: From fundamentals to nanocomposites. Materials Science and Engineering R. 2009. Vol. 63. No. 3. P. 100125.

18. Yu X., Shen Z., Cai CH. Millimeter wave electromagnetic interference shielding by coating expanded polystyrene particles with a copper film using magnetron sputtering. Vacuum. 2009. Vol. 83. P. 1438-1441.

19. Larrieua J., Held B., Martinez H., Tison Y. Ageing of atactic and isotactic polystyrene thin films 
treated by oxygen DC pulsed plasma. Surface and Coatings Technology. 2005. Vol. 200. No. 7. P. 2310-2316.

20. Sasai Y., Matsuzaki N., Kondo Sh., Kuzuya M. Introduction of carboxyl group onto polystyrene surface using plasma technology. Surface and Coatings Technology. 2008. Vol. 202. No. 22. P. 5724-5727.

21. Vessel A. Modification of polystyrene with highly reactive cold oxygen plasma. Surface and Coatings Technology. 2010. Vol. 205. No. 2. P. 490-497.

22. Moulder J. F. Handbook of X-ray Photoelectron Spectroscopy, 1995.

23. Yashao Ch., Qiang G., Haiyan W., Jinhong Y., Yanlin W., Peng L. Surface modification and biocompatible improvement of polystyrene film by $\mathrm{Ar}, \mathrm{O}_{2}$ and $\mathrm{Ar}+\mathrm{O}_{2}$ plasma. Applied Surface Science. 2013. Vol. 265. No. 6. P. 452-457.

24. http://arrow.dit.ie/cgi/viewcontent.cgi?article $=1037 \&$ context $=$ engschmeccon

25. http://www.eso.lt/lt/namams/elektra/esu-klientas/tarifai-kainos-atsiskaitymas-ir-skolos/ kiek-kainuoja-elektra-2016/koki-tarifo-plana-galiu-pasirinkti.html

26. http://www.bronkhorst.com/files/applications/ a002h_-_glass_coating.pdf

27. https://www.lesker.com/newweb/deposition_ sources/pdf/kjlced09_sec11_pages6-12_torusmagnetronsputteringcathodes.pdf
Šarūnas Varnagiris, Jolanta Donèlienė,

Simona Tučkute, Tomas Vonžodas, Martynas Lelis, Darius Milčius

\section{DALELIŲ İTERPIMAS İ POLISTIRENINIO PUTPLASČIO TŪRI PANAUDOJANT FIZIKINIO GARINIMO TECHNOLOGIJA}

\section{Santrauka}

Polistireninis putplastis (EPS) pasižymi unikaliomis savybėmis. Jis yra lengvas, pigus, turi gerą terminę izoliaciją. Dèl šių bei kitų putplasčio savybių jo pritaikymas yra labai ịvairus (pastatų šiltinimas, smūgi sugerianti medžiaga šalmuose, maisto konteineriai ir kt.). Pasaulyje nuolatos didejja putplasčio poreikis, griežtèja ir reikalavimai šiai medžiagai norit ją panaudoti specifinèse srityse. Siekiant pagerinti tam tikras putplasčio savybes, priemaišos yra ịterpiamos i putplasčio vidų arba formuojamos kaip dangos jo paviršiuje. Šiame darbe pristatomi titano dioksido $\left(\mathrm{TiO}_{2}\right)$ daleliu iterpimo i putplasčio tūrị rezultatai naudojant fizikinio garinimo (PVD) technologiją. Medžiaga, ant kurios nusodinamos $\mathrm{TiO}_{2}$ dangos, - pirminès (neišpūstos) putplasčio granulès. Prieš nusodinant $\mathrm{TiO}_{2}$, granulès buvo paveiktos plazmoje, kad būtų pasiekta geresnè paviršiaus adhezija. Plazma buvo generuojama naudojant impulsinị srovès šaltinị (dažnis $-20 \mathrm{kHz}$, ịtampa $-400 \mathrm{~V}$ ). Slègis plazmos poveikio metu $-1 \times 10^{-1} \mathrm{mbar}^{\mathrm{TiO}_{2}}$ dangų nusodinimas vyko iš karto paveikus plazma ir neištraukus bandinių $\mathfrak{i}$ oro aplinką. Šio proceso metu titano katodas naudotas kaip pirminè medžiaga. Dangų nusodinimas vyko reaktyvioje aplinkoje naudojant argono (82 \%) ir deguonies (18 \%) mišini. Slègis nusodinimo metu - $6 \times 10^{-3}$ mbar, galia $-240 \mathrm{~W}$. $\mathrm{TiO}_{2}$ dangos po išpūtimo suskilo į mažesnes daleles. Dalelès putplasčio tūryje yra pasiskirsčiusios tolygiai. Jų stabilumą parodo ir tai, jog veikiant putplastị aukšta temperatūra suformuota degiklio liepsnos, $\mathrm{TiO}_{2}$ dalelès neatšoka nuo putplasčio ir išlieka nepakitusios. Šis modifikuotas putplastis turi ir fotokatalitinių savybių, kurios buvo fiksuotos stebint metileno mèlio skaidrèjimą apšviečiant ji UV-B spinduliuote.

Raktažodžiai: polistireninis putpalstis, magnetroninis garinimas, atsparumas temperatūrai, inicijuotai degiklio liepsnos 